the United States. Further, the total maximum area coverage of the exploitable mineral deposits, numbering about 350 (ref. 4), will not exceed $4,500 \mathrm{~km}^{2}$ even allowing for a generous estimate of 10 to $15 \mathrm{~km}^{2}$ per deposit. A single mining area would also recuperate more rapidly once the deposit is exhausted. But large-scale deforestation may be prevented by such mining only if ore processing is done outside the rainforests (for example in the Brazilian coastal areas, where the required infrastructure already exists), and if access to the mines is strictly controlled to prevent proliferation of settlements.

Brazil has no population pressure, and has vast areas with good soils south of the Amazon. Therefore careful attention should be given to the natural resources of the Amazon and to ways to curtail the destruction of a unique tropical ecosystem and indigenous ethnic groups.

ANDREAS HOPPE

Geologisches Institut der

Albert-Ludwigs-Universität,

W-7800 Freiburg, Germany

1. Radulovich, R. Nature 346, 214 (1990).

2. Hoppe, A. (ed.) Amazonien: Versuch einer interdiszipli nären Annäherung (Naturforschende, Freiburg, 1990).

3. Ministério das Minas e Energia Sumário mineral (Departamento Nacional da Produçâo Mineral, Brasília, 1990)

4. Schobbenhaus, C. \& Coelho, C. (eds) Principais depósi-

tos minerais do Brasil (Departamento Nacional da Produção Mineral, Brasília, 1985-1988).

5. Fearnside, P.M. et al. Deforestation rate in Brazilian Amazonia (INPE/INPA, Sáo Paulo-Manaus, 1990).

\section{Curved saplings at Mount St Helens}

SIR - One of the most important effects of the eruption of Mount St Helens on 18 May 1980 was the blowdown of large trees by the lateral blast of hot volcanic ash and gas. Many of the large trees fell in the direction of this flow ${ }^{\mathrm{P}}$. During a recent visit to the blowdown area, we observed that the flow had a different effect on small saplings, $1-2 \mathrm{~m}$ in length. Although Douglas fir and Sitka spruce saplings perished in the high temperatures of the blast, many remained standing even in areas where larger trees had fallen. Another remarkable feature of those saplings that had grown on slopes was that they were consistently curved in the downslope direction, even in regions where the larger trees had fallen in the up- or along-slope direction, parallel to the flow ${ }^{1}$. These saplings were also stripped of limbs and bark, and had small cracks on the inner, downslope side of the curve, where they were slightly charred. In contrast, the upslope sides of the saplings were smooth.

Trees typically point downhill at a small angle when growing on a slope, and therefore experience a gravitational torque $^{2}$. Fir and spruce are softwood trees, which grow compressional reac- tion wood when under mechanical stress. Compression wood has relatively high compressive strength but low tensile strength. The strength of this reaction wood counteracts the net gravitational moment. Experiments suggest that, on drying, compression wood can contract longitudinally a few per cent, which is perhaps ten times as great as the contraction of regular wood ${ }^{3}$.

We believe that the saplings were curved by differential dehydration of compression wood (downslope) relative to regular wood (upslope) caused by the hot blast. During the eruption, the hot volcanic ash and gas flowed along the ground, felling the larger, more inflexible trees; however, the more elastic saplings remained standing. In several locales east and north of Spirit Lake, we estimated than the radii of curvature of the saplings were $120-240 \mathrm{~cm}$. The average thickness of the saplings was about 5 $\mathrm{cm}$. Based on this geometry, we calculate that the downslope side contracted about 4 per cent more than the upslope side. The presence of small near-surface contraction cracks on the downslope side suggests that slightly more differential contraction occurred following tensile failure of the compression wood. Our estimates of the total differential shrinkage of the saplings are in good agreement with experimental measurements of the shrinkage exhibited by drying both compression and regular wood ${ }^{3}$

In contrast to the mature trees which were blown down, saplings cannot be used as flow direction markers. However, the contraction and degree of curvature are functions of the amount of drying. So, sapling curvature, measured directly after an eruption, could be used to infer the temperature and duration of a volcanic flow. It is interesting to note that these saplings are natural analogues of bimetallic strips, except in this case curvature is induced by drying rather than temperature change.

Jet Propulsion Laboratory, MARCUS I. BURSIK

MS 183-501, Pasadena,

California 91109, USA

ANDREW W. WOODS Institute of Theoretical Geophysics,

20, Silver Street

Cambridge, CB3 9EW, UK

1. Lipman, P. W. USGS Prof. Pap. 1250 (1981)

2. Dinwoodie, J.M. Timber - its Nature and Behaviour (Van Nostrand Rienholdt, New York, 1981

3. Meylan, B. A. Forest Products J. 18, 75-78 (1968)

\section{Scientific Correspondence}

SCIENTIFIC Correspondence is intended to provide a forum in which readers may raise points of a scientific character. They need not arise out of anything published in Nature. In any case, priority will be given to letters of fewer than 500 words and five references.

\section{Wonky mice and MBP promoter}

SIR - Peter Parham ${ }^{1}$, in his News and Views article discussing our paper ${ }^{2}$, suggested that the integration sites of transgenes containing the myelin basic protein (MBP) promoter may have influenced the wonky phenotype. Although we agree that such sites may be important in influencing the level of protein expression, we believe that the chances of a transgene integrating into a site involved in normal MBP expression in two independently derived lines are extremely low. In addition, mice with a similar phenotype, resulting from an MBP promoter-driven class I MHC transgene construct, have more recently been reported ${ }^{3}$.

In many respects, wonky mice are similar to myelinating mutant mice, such as shiverer and mld, in which hypomyelination results from a lack of MBP expression. There are also important differences, as wonky mice die by 16-23 days whereas shiverer and mld mice survive for 5-6 months ${ }^{4}$. MBP gene expression in wonky mice is greater than in myelinating mutants, with $20-30 \%$ of normal MBP RNA levels (data not shown) compared to $<1 \%$ in shiverer mice ${ }^{5}$ and $3 \%$ in $m l d^{6}$. The myelin in shiverer and mld mice, where present, is poorly compacted and the major dense line is absent ${ }^{7}$; in wonky mice, the limited amount of myelin present is thin, yet compact and contains the major dense line. The fact that wonky mice and all the myelinating mutants, including Jimpy (in which the defect is in the proteolipid protein gene, not the MBP gene $)^{8}$, have a similar behavioural phenotype at around 12 days of age can be explained by the hypomyelination which becomes obvious at this stage of development even though the cause differs in each case.

We do not discount the role of the immune system in the pathogenesis of multiple sclerosis. We are simply proposing that increased levels of MHC molecules may per se be associated with dysmyelination.

A. M. TURNLEY G. MORAHAN P. BARTLETT

J. F. A. P. MILLER

Walter and Eliza Hall Institute of

Medical Research,

Royal Melbourne Hospital,

Victoria 3050, Australia

1. Parham, P. Nature 353, 503-505 (1991)

2. Turniey, A. M. et al. Nature 353, 566-569 (1991)

3. Yoshioka, T., Fiegenbaum, L. \& Jay G. Molec. cell. Biol. 11, 5479-5486 (1991)

Shen, X.-Y. et al. Brain Res. 360, 235-247 (1985)

5. Roach, A, et al. Cell 34, 799-806 (1983).

6. Okano $\mathrm{H}$ et al EMBO । 7,77-83 (1988)

7. Privat, A et al. Neurosci. Lett. 12, 107-112 (1979)

8. Hudson, L. D. et al. Proc. natn. Acad. Sci U.S.A. 84, 1454-1458 (1987) 